\title{
A study of systolic time intervals during uninterrupted exercise
}

Sir,

The report in this journal by Van der Hoeven and colleagues of the TNO $(1977,39,242)$ is a significant contribution to exercise data handling. However, there are several aspects of this work which may be criticised.

The authors have chosen to relate the pre-ejection period (PEP) to heart rate. Though they did not make the common mistake of directly proposing HR correction of PEP, the implication seems to be (or is not denied) that the HR-PEP association is causal. There is a large body of work to show that this is not likely (Simon et al., 1971; Talley et al., 1971; Atsumi et al., 1972; Fabian et al., 1972; Knapp et al., 1972; Higgins et al., 1973; Harris, 1974; Spitaels et al., 1974; Cokkinos et al., 1976; Urbaszek et al., 1976). Atrial pacing (that is, a pure rate effect) within wide limits of HR does not change PEP. The apparent relation between PEP and $H R$ in pooled resting data and under exercise and pharmacological challenges may be fortuitous. HR and PEP are simultaneously and in a parallel fashion under adrenergic influence. Thus, exercise, anxiety, and direct or pharmacological adrenergic stimulation cause heart rate and pre-ejection period to change pari passu.

The authors imply (p. 243) that measurements of systolic time intervals before this work ('thus far') were made only after interruption of upright exercise and changing to supine position, or by measuring postexercise intervals while supine. This is clearly erroneous, as we have been measuring systolic time intervals for the past 8 years during uninterrupted upright bicycle ergometer exercise (Pigott et al., 1971; Chirife and Spodick, 1972; Quarry-Pigott et al., 1973; Spodick and QuarryPigott, 1973; Spodick, 1973; Lance and Spodick, 1975; Xenakis et al., 1975; Lance and Spodick, 1976a, b; Spodick and Lance, 1976; Lance and Spodick, 1977; Nandi and Spodick, 1977). Curiously, buried in the discussion (p. 250), the authors do acknowledge one early investigation of ours, stating that our group, using a method comparable to theirs, 'found a spread which is about the same as that of our present study'. While the pos- ition of this reference is curious in itself, they should not have been so modest. Our results have indeed been comparable to theirs, including those in numerous papers preceding theirs. However, our TNO colleagues have done a much more extensive study with excellent investigation of clinical material, whereas our exercise studies heretofore have been methodological and physiological.

My colleagues and I can agree with these authors in their explanation of the pitfalls of measurements made immediately after exercise. Their study shows a phenomenon first noted by us (Chirife and Spodick, 1972): post-exercise fall in left ventricular ejection time, despite a rapid fall in heart rate. This seeming paradox is analysed more completely in further work on the exercise recovery period (Nandi and Spodick, 1977).

Finally, the authors imply that there is some mystery in obtaining systolic time intervals during uninterrupted exercise (p. 243: 'We have now developed a technique ...'). Those unfamiliar with noninvasive exercise testing should understand that obtaining technically good records with standard equipment, in fact, can be quite simple. It requires meticulous care in attaching sensors and in coaching co-operative subjects who can minimise upper body movements. There are no secrets as long as appropriate sensors and recording equipment are used. Recently, the method has been even further simplified by a series of developments by our group (Chirife and Spodick, 1972; Spodick and Lance, 1976); (Lance and Spodick, 1977). Not only can the phonocardiogram be dispensed with during actual exercise testing (Spodick and Lance, 1976) but the left ventricular ejection time can be obtained flawlessly by a simple and inexpensive ear densitograph (Chirife and Spodick, 1972; Lance and Spodick, 1977).

Despite these criticisms the TNO group has made a solid contribution to the analysis of exercise responses.

David H. Spodick,
Division of Cardiology,
St. Vincent Hospital,
Worcester, Mass. 1604, U.S.A. 


\section{References}

Atsumi, T., Matsunda, M., and Honda, Y. (1972). Systolic time intervals of the normal Japanese. Cardiovascular Sound Bulletin, 2, 367-371.

Chirife, R., and Spodick, D. H. (1972). Densitography: a new method for evaluation of cardiac performance at rest and during exercise. American Heart fournal, 83, 493-503.

Cokkinos, D. V., Heimonas, E. T., Demopoulos, J. N., Haralambakis, A., Tsartsalis, G., and Gardikas, C. D. (1976). Influence of heart rate increase in uncorrected preejection period/left ventricular ejection time (PEP/LVET) ratio in normal individuals. British Heart fournal, 38, 683-688.

Fabian, J., Epstein, E. J., and Coulshed, N. (1972). Duration of phases of left ventricular systole using indirect methods. I. Normal subjects. British Heart fournal, 34, 874-881.

Harris, W. S. (1974). Systolic time intervals in the noninvasive assessment of left ventricular performance in man. In Cardiac Mechanics, p. 238. Ed. by I. Mirsky, D. N. Ghista, and H. Sandler. Wiley, London.

Higgins, C. B., Vatner, S. F., Franklin, D., and Braunwald, E. (1973). Extent of regulation of the heart's contractile state in the conscious dog by alteration in the frequency of contraction. Fournal of Clinical Investigation, 52, 1187-1194.

Knapp, E., Aigner, A., Baumgartl, P., and Raas, E. (1972). Zur Frage der Frequenzabhängigkeit systolischer Kreislaufzeiten und daraus berechneter Indizes. Zeitschrift für Kreislaufforschung, 61, 492-497.

Lance, V. Q., and Spodick, D. H. (1975). Constant-load versus heart rate targeted exercise: responses of systolic intervals. Fournal of Applied Physiology, 38, 794-800.

Lance, V. Q., and Spodick, D. H. (1976a). Heart rate-left ventricular ejection time relations. Variations during postural change and cardiovascular challenges. British Heart fournal, 38, 1332-1338.

Lance, V. Q., and Spodick, D. H. (1976b). Ejection time-heart rate relationship during exercise. Catheterization and Cardiovascular Diagnosis, 2, 165-173.

Lance, V. Q., and Spodick, D. H. (1977). Systolic time intervals utilizing ear densitography: advantages and reliability for stress testing. American Heart fournal, 94, 62-66.

Nandi, P. S., and Spodick, D. H. (1977). Recovery from exercise at varying work loads. Time course of responses of heart rate and systolic intervals. British Heart fournal, 39, 958-966.

Pigott, V. M., Spodick, D. H., Rectra, E. H., and Khan, A. H. (1971). Cardiocirculatory responses to exercise: physiologic study by noninvasive techniques. American Heart fournal, 82, 632-641.

Quarry-Pigott, V. M., Chirife, R., and Spodick, D. H. (1973). Ejection time by ear densitogram and its derivative: clinical and physiologic applications. Circulation, 48, 239-246.

Simon, H., Fricke, G., and Esser, H. (1971). Herzdynamische zeitmasse und Kreislaufzeiten bei arterieller Hypertonie. Klinische Wochenschrift, 49, 193-198.

Spitaels, S., Arbogast, R., Fouron, J. C., and Davignon, A. (1974). The influence of heart rate and age on the systolic and diastolic time intervals in children. Circulation, 49, 1107-1115.

Spodick, D. H. (1973). Polygraphic evaluation of the performance of the heart. Cardiovascular Sound Bulletin, 3, 285-297.

Spodick, D. H., and Lance, V. Q. (1976). Noninvasive stress testing: methodology for elimination of the phonocardiogram. Circulation, 53, 673-676.

Spodick, D. H., and Quarry-Pigott, V. M. (1973). Effects of posture on exercise performance: measurement by systolic time intervals. Circulation, 48, 74-78.

Talley, R. C., Meyer, J. F., and McNay, J. L. (1971). Evaluation of the pre-ejection period as an estimate of myocardial contractility in dogs. American fournal of Cardiology, 27, 384-391.

Urbaszek, W., Löwe, H. R., Rentsch, W., Pankau, H., and Günther, K. (1976). Die Beurteilung der Herz-KreislaufRegulation mit dem sog. Anspannungsindex. Zeitschrift für die gesamte innere medizin und ihre Grenzgebiete, 31, 567-574.

Xenakis, A. P., Quarry, V. M., and Spodick, D. H. (1975). Immediate cardiac response to exercise: physiologic investigation by systolic time intervals at graded work loads. American Heart fournal, 89, 178-185.

This letter was shown to the authors who reply as follows.

Sir,

First, our apologies for not sufficiently emphasising the contributions of Dr Spodick's group. In fact, our original manuscript submitted to the journal in 1975 included many more references, but we were asked to shorten it to its eventual form. One of the references was an article by Willems and Kesteloot (1967) which pointed out that, since many heart patients still display normal haemodynamics at rest, it would be of interest to study the LVET in such patients during exercise. Indeed, this is but one example of the many reported investigations which motivated us to carry out our study.

The goal of our study was to find noninvasive measurements for clinical diagnosis of heart patients. We have, after a great deal of data reduction, found a linear relation between PEP and RR interval for the circumstances of our study (Van der Hoeven et al., 1973), viz, upright graded exercise. We never assumed or claimed a causal relation between these two indices or that the linear relation exists for other circumstances.

There have been a number of previous studies on systolic time intervals (STI) obtained during uninterrupted upright exercise, as we acknowledge in our article. Dr Spodick is kind enough to point out, however, that our results show a considerable improvement in the diagnostic value of STI's over previous studies. We do not claim that there is any 'mystery' in obtaining STI's during uninterrupted exercise. However, Dr Spodick in one of his own articles (Chirife and Spodick, 1972) makes such statements as 'the difficulties to get STI's during exercise', 'none of the techniques will be appliable during exercise', etc.

As far as obtaining the LVET with sufficient fidelity to enable automatic detection (Donders et al., 1977), we found our Pixie transducer applied to the 
carotid artery to be superior to all other available techniques.

G. M. A. van der Hoeven,

P. J. A. Clerens,

J. J. H. Donders,

J. E. W. Beneken,

J. T. C. Vonk,

University of Nijmegen, Div. of

Cardiology and Institute of Medical

Physics, TNO, The Netherlands.

\section{References}

Chirife, R., and Spodick, D. H. (1972). Densitography: a new method for evaluation of cardiac performance at rest and during exercise. American Heart fournal, 83, 493-503.

Donders, J. J. H., Van der Hoeven, G. M. A., Snoeck, B., and Beneken, J. E. W. (1977). A processing system for the determination of systolic time intervals. In Biomedical Computing, p. 68. Ed. by W. J. Perkins. Pitman, Tunbridge Wells, Kent.

Van der Hoeven, G. M. A., Beneken, J. E. W., and Clerens, P. J. A. (1973). A new atraumatic technique of recording systolic time intervals at rest and during exercise. Netherlands Fournal of Medicine, 16, 70-78.

Willems, J., and Kesteloot, H. (1967). The left ventricular ejection time. Its relation to heart rate, mechanical systole and some anthropometric data. Acta Cardiologica, 22, 401-425. 